\title{
POLITICO-ECONOMIC REGIMES AND ATTITUDES: FEMALE WORKERS UNDER STATE SOCIALISM
}

\author{
Pamela Campa and Michel Serafinelli*
}

Abstract-This paper investigates whether attitudes are affected by politicoeconomic regimes. We exploit the efforts of state socialist regimes to promote women's economic inclusion. Using the German partition after World War II, we show that women from East-Germany are more likely to place importance on career success compared to women from West-Germany. Further, the population at large in East Germany is less likely to hold traditional gender role attitudes. Examining possible mechanisms, we find that the change in attitudes under the East German regime was larger in areas where the growth in female employment was larger. A comparison of Eastern versus Western Europe confirms these results.

\section{Introduction}

$\mathrm{T}^{0}$ what extent are attitudes affected by politico-economic regimes and government policies? We focus on female attitudes toward work and gender-role attitudes in the population at large. These attitudes differ considerably over time and space ${ }^{1}$ and have been shown to have significant effects on labor market outcomes. $^{2}$

Answering the question of whether politico-economic regimes affect attitudes is complicated due to the fact that regimes are not randomly assigned. ${ }^{3}$ In this paper, we exploit the imposition of state socialist regimes across Central and Eastern Europe after World War II. Between their rise

Received for publication August 1, 2016. Revision accepted for publication April 20, 2018. Editor: Asim I. Khwaja.

*Campa: SITE - Stockholm School of Economics; Serafinelli: University of Essex and IZA.

We thank Philippe Aghion, Miguel Almunia, Vladimir Asriyan, Manuel Bagues, Michael Baker, Natalie Bau, Kaspar Beelen, Gustavo Bobonis, Chris Bruce, David Card, Francisca de Haan, Jan deVries, Sebastian Findeisen, Louise Grogan, Ian Heffernan, Yosh Halberstam, Jonas Hjort, Mitchell Hoffman, Carlos Inoue, Anne Karing, Nicholas Li, Arvind Magesan, Fruzsina Mayer, Nicola Mastrorocco, Robert McMillan, Joan Monras, Tommaso Nannicini, Adam Miettinen, Gillian Petit, Torsten Persson, Swapnika Rachapalli, Helmut Rainer, Gerard Roland, Seyhun Orcan Sakalli, Fabio Schiantarelli, Blake Shaffer, Dhruv Sinha, Aloysius Siow, David Stromberg, Guido Tabellini, Shqiponja Telhaj, Petra Thiemann, Heike Trappe, Ana Tur-Prats, Alex Whalley, Genet Zinabou, Natalia Zinovyeva, and participants in presentations for helpful comments; Leonardo Bursztyn and Davide Cantoni for sharing data on availability of signal from TV stations; Benjamin Couillard, Danny Edgel, and Alexander Hempel for excellent research assistance; and staff at DIW Berlin and GESIS Cologne for assistance with GSOEP and ALLBUS.

A supplemental appendix is available online at http://www.mitpress journals.org/doi/suppl/10.1162/rest_a_00772.

${ }^{1}$ Giavazzi, Schiantarelli, and Serafinelli (2013) observe variation in these attitudes over time for the period 1980 to 2000 in European regions and OECD countries.

${ }^{2}$ Fortin (2008) presents evidence that gender differences in attitudes toward work have a significant role in accounting for the gender wage gap. Further, Fernández, Fogli, and Olivetti (2004), and Fernández and Fogli (2009) show a substantial effect of gender-role attitudes on women's labor force participation. In a similar vein, Bertrand, Kamenica, and Pan (2015) present evidence that gender identity norms have an impact on women's labor force participation, the gender gap in income, the distribution of relative income within households, and the division of home production.

${ }^{3}$ See Aghion, Algan, and Cahuc (2011), Michau (2013), and Alesina et al. (2015) for theoretical analyses of the two-way causality between policies and cultural attitudes. to power in the late 1940s and up to the late 1960 s, state socialist governments throughout the region made efforts to promote women's economic inclusion; their rapid industrialization and general plan for economic growth (which was based on an intensive use of labor) were dependent on such inclusion (de Haan, 2012). Moreover, women's economic independence was seen as a necessary precondition for women's equality, a principle to which these governments were arguably committed, though many scholars claim that the need for female labor power was by far more relevant (see, e.g., Buckley, 1981). Legal changes such as the adoption of the principle of equal work under equal conditions, new family laws, and education and training policies were used to further this goal (Shaffer, 1981; Wolchik, 1981; Fodor, 2002). Easy access to abortion also helped women's entry into the workforce (David, 2013). Within this historical context, we empirically investigate the role that political regimes played in influencing attitudes.

In our main analysis, we make use of the German Socioeconomic Panel (GSOEP), a longitudinal survey of households residing in Germany. We exploit quasi-experimental variation in political regimes and government policies in postwar Germany. Before 1945, the politico-economic system was the same in East and West Germany. After 1945, the country was split in two, with women in the East and West becoming exposed to very different institutions and policies. East Germany focused (particularly during the 1960s) on policies that favored female qualified employment, while West Germany encouraged a system in which women either stayed home after they had children or were funneled into part-time employment after an extended break (Trappe, 1996; Shaffer, 1981).

The historical circumstances suggest that we can contrast attitudes toward work in the sample of women who, before reunification, had lived in East-Germany versus those who had lived in West Germany. Thus, we estimate an equation that compares attitudes East and West of the inner German border for women and men. Attitudes toward work are measured using a question about the importance of career success for the respondent that was asked in 1990 before the process of unification was completed. The timing of the question is important because it allows us to disentangle the effects of living in a state socialist country from that of living in a postsocialist country. A potential concern is that the OLS estimates of the difference in attitudes between individuals who lived in East Germany and individuals who lived in West Germany may be biased due to local unobserved heterogeneity before the separation, which some evidence suggests may be relevant in our setting (see section IIIB). In order to address this potential issue, we use a spatial regression discontinuity framework 
(Black, 1999; Lalive, 2008; Dell, 2010; Schumann, 2014) to compare only those individuals who lived close to the EastWest border prior to reunification. The underlying assumption is that individuals who lived spatially close to each other in this area had similar attitudes before the separation.

We hypothesize that female employment and attitudes were affected by policies targeting women. Attitudes and female employment may then also influence one another. Unfortunately, the research design and available data prevent us from determining the relative importance of the several policy differences between East and West Germany. However, in order to crack open the black box of regime influence, we explore and provide suggestive evidence on the relationship between local female employment and attitudes and the role of propaganda.

Our main estimates show that in 1990, the East-West difference in attitudes toward work is significantly larger for women than for men. In the OLS estimates, the East-West difference in the likelihood of reporting that career success is important for women versus men is 10 percentage points. The spatial regression discontinuity (RD) results are similar. In general, both women and men seem to attribute more importance to work in East Germany, but the East-West difference for men is significant only in the OLS specification, and it is always less than half as large as that observed for women. ${ }^{4}$ The East-West difference for women versus men in attitudes (and employment) appears to persist after reunification.

To examine the potential channels of influence, we first employ an IV strategy in the spirit of Moretti (2013) and show suggestive evidence that the change in women's attitudes toward work was larger in areas where the change in female employment was larger, consistent with Fogli and Veldkamp (2011). ${ }^{5}$ Second, we analyze the extent to which women in East Germany were affected by government propaganda by (a) employing individual-level proxies for ideology, (b) exploiting plausibly exogenous spatial variation in the availability of West German TV in the East (Bursztyn \& Cantoni, 2015), and (c) exploiting plausibly exogenous variation in the time spent in school learning the foundations of the socialist system (Fuchs-Schündeln \& Masella, 2016). We fail to reject the null hypothesis of no propaganda effect on attitudes (although when using the second approach, the standard errors are quite large and prevent us from drawing definitive conclusions).

\footnotetext{
${ }^{4}$ The evidence strongly suggests that the identified East Germany effect does not reflect a general pattern in attitudes toward work but instead is due to an increased focus on female economic inclusion.

${ }^{5}$ Specifically we regress the difference between the attitudes of East German "young" female cohorts (born after 1935) and those of "old" female cohorts (born before 1935) in county $c$ on the change in the female employment rate between 1950 and 1985 in district $d$. The basic intuition behind the IV approach is the following: if employment in a relatively feminized industry increases nationally, districts where the industry employs a relatively large share of the labor force will experience a relatively large increase in female employment.
}

We also make use of the German General Social Survey (ALLBUS), which allows a comparison of gender role attitudes in East and West Germany; the first year when we can analyze these data is 1996 . We find that gender-role attitudes of both women and men are less traditional in East versus West Germany. ${ }^{6}$

Next, we broaden our focus to state socialism throughout the entire Central and Eastern European region. We employ a difference-in-differences strategy that compares gender-role attitudes formed in Central and Eastern European countries (CEECs) versus Western European countries (WECs), before and after the imposition of state socialism in CEECs. Similar to the argument already made for Germany, we maintain that the imposition of state socialist regimes across Central and Eastern Europe constitutes a quasi-experiment that can be exploited to study whether attitudes are endogenous to politico-economic regimes. To this end, we need to obtain a time-varying measure of attitudes, which is problematic because of data limitations. ${ }^{7}$ We cope with this challenge by using data on the attitudes of U.S. immigrants and their offspring to construct a time-varying measure of attitudes in the respondents' source countries. This is motivated by a body of work that has noted and exploited the relationship between the behavior of immigrants and that of residents in their countries of origin (Giuliano, 2007; Fernández \& Fogli, 2009; Antecol, 2000) and by evidence that the parents' gender-role attitudes are a useful predictor of the attitudes of children (Farré \& Vella, 2013; Dhar, Jain, \& Jayachandran, 2015). ${ }^{8}$

Using the country of origin of U.S. immigrants who immigrate over time (and the attitudes inherited by their offspring), we capture the over-time variation of gender-role attitudes in the source countries. For example, by contrasting U.S. residents of Spanish and Polish origin who migrated between 1945 and 1990 and their offspring, we identify differences in gender-role attitudes formed in Spain and Poland during this time. We then obtain a time-varying measure of attitudes in these two countries by implementing the same procedure for U.S. residents (and their offspring) who immigrated between 1900 and $1945 .^{9}$

Our measure of attitudes is taken from the General Social Survey (GSS), which collects data on the contemporaneous gender-role attitudes of U.S. residents, and information that allows us to infer their approximate period of immigration or that of their ancestors. This approach enables us to track the variation in gender-role attitudes in

\footnotetext{
${ }^{6} \mathrm{We}$ use, for convenience, the term traditional to reflect the opinion that women should specialize in home production and men in market production.

${ }^{7}$ The 1980s is the earliest period in which a measure of gender-role attitudes in cross-country surveys is available.

${ }^{8}$ Fernández (2007) also delivers an empirical test of the intergenerational transmission of attitudes by showing that source-country attitudes toward women's work in 1990 predict the labor supply of second-generation American women in 1970. For a discussion of the intergenerational transfer of other attitudes, such as trust, see Guiso, Sapienza, and Zingales (2006).

${ }^{9}$ The first time period, 1945 to 1990, refers to the period with socialist "treatment" in CEECs, while the second time period, 1990 to 1945 , is a pretreatment time period for both CEECs and WECs.
} 
nineteen European countries-five in the "treatment" group and fourteen in the "control" group. Employing this measure of gender-role attitudes with intertemporal variation, we estimate the relationship between the change in the politicoeconomic regime and the evolution in women and men's gender-role attitudes. We show that prior to the imposition of the new politico-economic regime, gender-role attitudes in CEECs appear to have evolved in a manner similar to attitudes in WECs. These attitudes appear to have become significantly less traditional in CEECs versus WECs after 1945. We show that it is unlikely that the estimated relationship reflects differential changes in the selection of immigrants in CEECs and WECs after the imposition of state socialism.

The remainder of this paper is organized as follows. In section II, we relate our research to the existing literature. Section III discusses the analysis exploiting the German separation. The difference-in-differences analysis that compares CEECs and WECs using the GSS is presented in section IV. Section V concludes.

\section{Relation to Previous Literature}

By combining concepts regarding institutions and attitudes in an original manner, our study adds to a growing literature on related issues. The first related body of work, surveyed in Alesina and Giuliano (2015), analyzes the effects of large institutional changes on attitudes. One set of papers studies communities belonging to different states to isolate the effects of formal institutions on attitudes (Peisakhin, 2010; Becker et al., 2016; Grosfeld \& Zhuravskaya, 2015; Wysokinska, 2015; Lowes et al., 2017). Another set of papers within this body of work uses the advent of state socialism as a source of institutional change. Most notably, the seminal study by Alesina and Fuchs-Schundeln (2007) analyzes preferences for redistribution in Germany in 1997 and 2002 and finds that East Germans are more pro-state than West Germans are.$^{10}$ In addition to the focus on different outcomes (female attitudes toward work and gender-role attitudes as opposed to preferences for redistribution), our work builds on the analysis in the Alesina et al. (2007) study in several ways. First, we disentangle the effects of having lived in a state socialist country from that of living in a postsocialist country. Second, we directly assess the empirical relevance of selective East-West migration in Germany. Third, through our spatial regression discontinuity design, we guard against the possibility that the estimates of the regime effect in Germany are due to historical (i.e., pre-1949) local unobservable determinants of attitudes. Fourth, we provide suggestive evidence on the extent to which state socialism affects attitudes in the broader Central and Eastern European region. ${ }^{11}$

\footnotetext{
${ }^{10} \mathrm{Kim}$ et al. (2015) exploit the division of Korea to investigate whether institutions affect social preferences.

${ }^{11}$ Related to our work are also the recent studies by Bauernschuster and Rainer (2011), Beblo and Goerges (2015), and Lippmann, Georgieff, and Senik (2016). The first paper uses the ALLBUS, the German equivalent to the GSS, for the period 1991-2008 and shows that being from East Ger-
}

The second related body of work investigates the determinants of cultural attitudes and their transmission (Bisin \& Verdier, 2001; Tabellini, 2008; Durante, 2009; Voigtländer \& Voth, 2012; Alesina, Giuliano, \& Nunn, 2013; Gorodnichenko \& Roland, 2017). The central message of this literature is that attitudes have a component that is quite persistent. Yet this message does not imply that attitudes are absolutely invariant, a point well made by Algan and Cahuc (2010) and Giavazzi, Petkov, and Schiantarelli (2014). Our study blends these different views by acknowledging that an element of attitudes can be transmitted within families but that attitudes can also change as a reaction to shocks in institutions and economic incentives. ${ }^{12}$ The European ancestors of modern Americans experienced very different politicoeconomic regimes. Specifically, ancestors from CEECs who migrated after 1945 were influenced by the advent of state socialism. We show suggestive evidence of a change in genderrole attitudes following a regime change and of these attitudes being transmitted within families.

\section{Analysis Exploiting the German Separation}

\section{A. Data and Variables}

We use data from the German Socioeconomic Panel (GSOEP), a longitudinal survey of German households launched in West Germany in 1984 and conducted annually. As of 1990, households residing in the former GDR were included in the GSOEP. In 1990, 6,695 individuals in West Germany (around March) and 4,304 in East Germany (around June) answered a survey question about the importance of career success to them. ${ }^{13}$ For the West German sample, the question reads: "Different individuals find different things in life important. How important are the following things to you today? Succeed in one's occupation." 14 For the East German

many is associated with a lower likelihood of believing that segregation of male and female roles is appropriate. The second paper uses three waves of ALLBUS (1991, 1998/2000, and 2010/2012) and shows that the gender gap in preferences toward work is smaller in East versus West Germany, consistent with an impact of "nurture" on preference formation. The third paper uses the GSOEP for the period 1991-2012 and shows that in East Germany, women can earn more than their spouse without having to overplay their feminine role (by spending more time on housework) or putting their marriage at risk. We extend the empirical approach used in these three studies in the same ways as we extend the one in Alesina and Fuchs-Schundeln (2007).

${ }^{12}$ Giuliano and Spilimbergo (2014) present evidence that the historical macroeconomic environment affects preferences for redistribution; $\mathrm{Di}$ Tella, Galiant, and Schargrodsky (2007) show that obtaining land rights affects an extensive set of attitudes; Bau (2015) studies relatively small policy changes and finds heterogeneous responses to these policies by different ethnic groups over just a few years and a rational decline of traditional practices as a result of the policies.

${ }^{13}$ We restrict our sample to the 1990 GSOEP subsamples that are representative of the respective populations: GSOEP subsamples A and C. For details about the GSOEP sample, see https://www.diw.de/en/diw_02.c .299726.en/soep_overview.html\#299735.

${ }^{14}$ The same question was repeated, in sequence, for the following items: (1) Able to afford something; (2) Be there for others; (3) Fulfill oneself; (4) Succeed in one's occupation; (5) Own a house; (6) Have a good marriage/partnership; (7) Have children; (8) Be together with friends 
sample, the question reads: "Which of the following things are very important, important, not so important, or unimportant to your sense of well-being and personal satisfaction? Your career success." ${ }^{15}$ Responses are coded into a unique variable by GSOEP on a scale from 1 to 4 corresponding to, respectively, "unimportant," "not very important," "important," and "very important." We group the answers "unimportant" and "not very important" under 0 and "very important" and "important" under 1 . We call the resulting variable Job Success Important. When it takes a value of 1, the respondent puts a higher value on career success. Table A.1 reports summary statistics for our baseline sample. One potential concern is that the differences in responses between East and West German women might be caused by the slightly different phrasing of the question they were asked. To address this concern, in section IIIC, we show that our main estimates are unchanged when we measure attitudes in 1992, when exactly the same question is asked in both East and West Germany. ${ }^{16}$ Additionally, we show that our main results regarding the East-West difference in women's attitudes do not hold for the sample of East and West German men interviewed by the GSOEP. Finally, the grouping of the four categories of answers into 0 and 1 arguably makes the answers of East and West Germans more comparable. ${ }^{17}$

Individuals are also, asked, "Where did you live in 1989: East or West?" As in Alesina and Fuchs-Schundeln (2007), we create the dummy East that takes the value of 1 if the respondent lived in East Germany in $1989 .{ }^{18}$ Further, we use restricted access information about respondents' place of residence at the time of the interview. ${ }^{19}$ In section IIIC we discuss additional data that allow us to address the issue of selective East-West migration.

\section{B. Framework and Empirical Strategy}

Our goal is to investigate whether attitudes are affected by politico-economic regimes. The institutional background of the German separation (see section A.I.i in the online appendix for a detailed discussion) suggests an empirical strat-

often; (9) Be politically/socially involved; (10) See the world; (11) Travel frequently.

${ }^{15}$ The same question is repeated, in sequence, for the following items: (1) Your work; (2) Your family; (3) Your friends; (4) Your income; (5) Your power to influence political decisions; (6) Your career success; (7) Your leisure time; (8) Your health; (9) The protection of the environment.

${ }^{16}$ In 1992 the GSOEP asked both East and West Germans, Different individuals find different things in life important. How important are the following things to you today? Succeed in one's occupation." Nevertheless, we choose to focus on 1990 in the main part of the analysis because this better serves our goal of identifying the effect on attitudes of having lived in a state socialist country versus that of living in a postsocialist country.

${ }^{17}$ Estimates are nevertheless very similar if the original coding for the question is used (results available on request).

${ }^{18}$ Six women moved from East to West and three from West to East between 1989 and 1990. We drop these women from the sample.

${ }^{19}$ Due to confidentiality reasons, this version of the GSOEP data set with sensitive regional data can be accessed and analyzed only on the premises of DIW Berlin or remotely, by preparing a job request for each step of the analysis that is screened and processed by local staff. egy that compares women who lived in East versus West Germany during the separation period. One might in principle interpret any differences between them as the result of exposure to different regimes. In practice, we use the full sample of German individuals and estimate an equation that compares attitudes East and West of the inner border for women and men. The regression equation that forms the basis of our empirical analysis for the sample of individuals in the GSOEP is

$$
\begin{aligned}
Y_{i c}= & \beta_{0}+\beta_{1} \text { East }_{c}+\beta_{2} \text { Female }_{i}+\beta_{3} \text { East }_{c} \\
& \times \text { Female }_{i}+\varepsilon_{i c},
\end{aligned}
$$

where the dependent variable is Job Success Important for individual $i$ living in county $c$, and East $c_{c}$ is a dummy for having lived in the GDR, as already defined. The coefficient $\beta_{1}$ captures the difference between men in East Germany and men in West Germany. The coefficient $\beta_{2}$ captures the difference between women and men in the West. Our main coefficient of interest is the one on the interaction $\left(\beta_{3}\right)$, which captures the East-West difference in attitudes for women versus men. The identifying assumption underlying this approach is that East and West Germany were not systematically different before the forced division of the country along dimensions that would influence the outcome of interest. Previous evidence provides somewhat mixed support for the appropriateness of this assumption. On the one hand, Alesina and FuchsSchundeln (2007) show that East and West Germany were similar on average before separation in terms of income; the percentage of the population working in industry, agriculture, or commerce; and support for the Social Democrats. On the other hand, Klüsener and Goldstein (2016), using data between 1840 and 1940, show that there was higher nonmarital fertility in regions that would become part of East Germany. Bauernschuster and Falck (2015) document spatial variation in child care coverage for the period 1834 to 1905 , with an important role played by cultural proximity to Bad Blankenburg, Thuringia, a region that would become part of East Germany. (Bad Blankenburg is where Friedrich Froebel, the leader of the kindergarten movement in the nineteenth century established his first institution.) To further investigate this issue, we have digitized data from the 1925 edition of the German census. As shown in table A.6, column 1, gender equality in employment in 1925 was between 2 and 3 percentage points lower in the portion of the country that would became the GDR. (For details on our measures of gender equality in employment and sample selection, see section A.I.ii). ${ }^{20}$

In principle, given that nonmarital fertility, child care coverage, and gender equality in employment may be related to the (unobservable before separation) attitudes of interest in our study, the comparison of East and West Germany in equation (1) might fail to deliver causal estimates in our

\footnotetext{
${ }^{20}$ If anything, these estimates suggest that the attitudes toward female work were more negative in the East prior to socialism.
} 
Table 1.-Job Success Important. Differences between Women and Men

\begin{tabular}{|c|c|c|c|c|c|}
\hline & (1) & $<=200 \mathrm{~km}$ & $<=150 \mathrm{~km}$ & $<=100 \mathrm{~km}$ & $<=\stackrel{(5)}{=} 50 \mathrm{~km}$ \\
\hline \multirow[t]{3}{*}{ East } & 0.047 & 0.011 & 0.024 & 0.043 & 0.068 \\
\hline & $(0.011)^{* * *}$ & $(0.023)$ & $(0.027)$ & $(0.034)$ & $(0.048)$ \\
\hline & $(0.012)^{* * * *}$ & $(0.033)$ & $(0.039)$ & $(0.049)$ & $(0.067)$ \\
\hline \multirow[t]{3}{*}{ Female } & -0.194 & -0.168 & -0.166 & -0.164 & -0.187 \\
\hline & $(0.011)^{* * *}$ & $(0.017)^{* * *}$ & $(0.020)^{* * *}$ & $(0.026)^{* * * *}$ & $(0.037)^{* * *}$ \\
\hline & $(0.010)^{* * *}$ & $(0.013)^{* * *}$ & $(0.015)^{* * *}$ & $(0.019)^{\text {*** }}$ & $(0.026)^{* * *}$ \\
\hline \multirow[t]{3}{*}{ Female $\times$ East } & 0.100 & 0.070 & 0.065 & 0.059 & 0.075 \\
\hline & $(0.017)^{* * *}$ & $(0.022)^{* * *}$ & $(0.026)^{* *}$ & $(0.032)^{*}$ & $(0.046)$ \\
\hline & $(0.014)^{* * *}$ & $(0.018)^{* * *}$ & $(0.021)^{* * *}$ & $(0.025)^{* *}$ & $(0.034)^{* *}$ \\
\hline Observations & 9,883 & 7,543 & 5,602 & 3,755 & 1,934 \\
\hline Adjusted $R^{2}$ & 0.048 & 0.035 & 0.031 & 0.028 & 0.034 \\
\hline Border segment FEs & No & Yes & Yes & Yes & Yes \\
\hline
\end{tabular}

Robust standard errors in parentheses (below: clustered, allowing for arbitrary correlations within counties). Significant at ${ }^{* * *} 1 \%,{ }^{* *} 5 \%$, and ${ }^{*} 1 \%$.

context. In order to address this potential concern, we attempt to account for historical local differences in unobservables by building on the spatial RD design framework. The basic idea is to place more weight on observations that are closer to the border versus those farther away. Such a comparison identifies the effect of politico-economic regimes under the assumption that the attitudes of those who lived in areas close to the border had been similar before separation (i.e., all the pre-1949 relevant factors besides treatment vary smoothly at the border). In the spatial RD, the running variable is twodimensional. As recommended by Imbens and Zajonc (2011), we collapse it to one dimension, thus using distance from the border as our running variable (Black, 1999; Lalive, 2008; Schumann, 2014). Specifically, we measure the Euclidean distance between the centroid of each respondent's county of residence and the East-West German border (figure A.2). ${ }^{21}$ Following the recommendation in recent work by Gelman and Imbens (2014), we estimate a local linear RD polynomial that controls linearly for distance from the border and weights observations by proximity to the border using a triangular kernel.

The regression equation is:

$$
\begin{aligned}
Y_{i c b}= & \beta_{0}+\beta_{1} \text { East }_{c}+\beta_{2} \text { Female }_{i}+\beta_{3} \text { East }_{c} \times \text { Female }_{i} \\
& +\beta_{4} \text { Distance }_{c}+\beta_{5} \text { Distance }_{c} \times \text { East }_{c}+\phi_{b}+\varepsilon_{i c b},
\end{aligned}
$$

where Distance $_{c}$ is distance from the border (with West German distances listed as negative values) and $\phi_{b}$ is a set of border-segment fixed effects that denote which of four equally sized portions of the East-West border is closest to the county of residence of individual $i$. The motivation for the inclusion of $\phi_{b}$ is to capture unobserved heterogeneity along a north-south dimension. ${ }^{22}$ The weights we use are

\footnotetext{
${ }^{21}$ See section A.I.iii for a discussion of potential measurement error in our running variable.

${ }^{22}$ Results are qualitatively similar when omitting these border-segment FEs. The analysis excludes Berlin because of its peculiar status (with West Berlin politically aligned to the FRG but surrounded by GDR territory) and particularly strong concerns of selective migration. As Cooper (1998, p. 57)
}

equal to $p w=\max \left(0\right.$, bandwidth $-a b s\left(\right.$ Distance $\left.\left._{c}\right)\right)$. Results are shown for bandwidths between 200 and $50 \mathrm{~km}$ from the border. Our spatial RD estimates with the two measures of gender equality in employment in 1925, reported in columns 2 to 4 of table A.6, lend support to the hypothesis that areas East and West of the border closer to each other are more comparable than areas farther away. In particular, for bandwidths of $150 \mathrm{~km}$ and smaller, there is no significant difference in gender equality in employment between East and West Germany in $1925 .^{23}$

It is important to note that we do not expect the state socialist treatment to be unrelated to other observables. On the contrary, we believe that the state socialist regime in East Germany may have influenced some socioeconomic variables during the period. What is key for our identification strategy is that the state-socialist treatment can be considered an "exogenous" institutional shock, a view supported by historical accounts about the process that led to the German separation after World War II (see Becker et al., 2016 for a discussion in a similar context). ${ }^{24}$ Section A.I.v reports the findings on the extent to which the regime influenced other demographic and socioeconomic variables.

\section{Estimation Results}

Main estimates. Column 1 of table 1 presents the main estimates of the analysis exploiting the German separation. We estimate equation (1) that compares attitudes east and west of the inner border for women and men. We report two standard errors, robust and clustered, that allow for arbitrary patterns of correlation within counties. The estimated coefficient on the

puts it: "East Berlin, with its proximity to the West, was a magnet for young people and dissidents. West Berlin attracted young draft resisters (Berlin's occupied status meant draft laws did not apply there) and people looking for an alternative to the bland materialism of postwar West Germany."

${ }^{23}$ Notice that since we estimate a local linear regression, an additional assumption that is required for identification is that the linear polynomial in distance approximates well the effect of distance on attitudes.

${ }^{24}$ Becker et al. (2016) focus on the Habsburg Austrian Empire, known for its localized and well-respected administration, and compare communities on both sides of the long-gone border. They find that historical Habsburg affiliation increases current trust. 

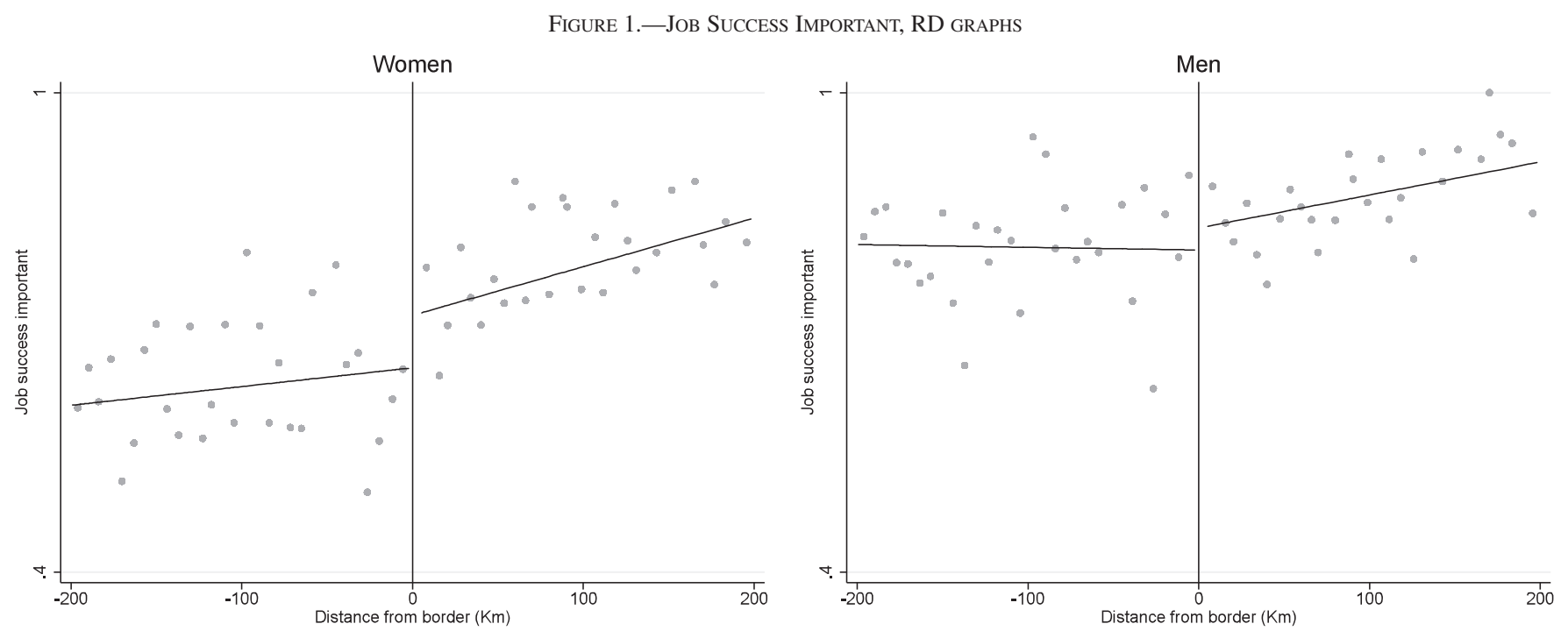

The figure shows bin averages and a linear fit for women and men in GSOEP. Specifically, the lines are fitted values from a regression of Job Success Important on distance, estimated on the two sides of the border The size of the bins is a little over $5 \mathrm{~km}$, chosen to have thirty bins on each side. The left side is West Germany. The variable Job Success Important is constructed using answers to the question on how important career success is for the individual's personal satisfaction. Bandwidths to construct polynomial fit are chosen to span the full support of the data. See Calonico, Cattaneo, and Titiunik (2015) for details.

dummy East implies that the difference between men in East Germany and men in West Germany is 4.7 percentage points; the estimated coefficient on the dummy Female implies that the difference between women and men in the West is 19.4 percentage points; and the coefficient on the interaction (our main object of interest) implies that the East-West difference in attitudes for women versus men is 10 percentage points.

Estimates of equation (2) are reported in columns 2 to 5 showing results for progressively smaller bandwidths (from 200 down to $50 \mathrm{~km}$ ). These spatial RD estimates are similar to the OLS ones. Across all specifications, the East-West difference in attitudes is larger for women than for men (i.e., the estimated $\beta_{3}$ is positive).

In general, both women and men seem to attribute more importance to work in East Germany, but the East-West difference for men $\left(\widehat{\beta_{1}}\right)$ is significant only in the OLS specification, and it is always less than half as large as that observed for women $\left(\widehat{\beta}_{1}+\widehat{\beta}_{3}\right)$. When we turn to the spatial RD, the estimated $\beta_{1}$ is larger than the standard error only in one specification. Our results can be visualized in RD graphs. The left panel of figure 1 shows bin averages and a linear fit for Job Success Important in the sample of German women. A discontinuity can be observed, with more positive attitudes toward work for women on the East side of the border. We interpret this discontinuity as the regime impact on attitudes. The right panel of figure 1 shows bin averages and a linear polynomial fit for Job Success Important in the sample of men. A comparison of the left and right panels of figure 1 suggests that the effect identified is genuine to the promotion of female employment and does not reflect a general pattern in attitudes toward work. Specifically, while a discontinuity can be easily observed for women, the same cannot be said for men.

Local female employment and attitudes. In order to examine the potential channels of influence (see figure A.1 for a summary of our conceptual framework), we turn to the relationship between local female employment and female attitudes toward work in the sample of East German women. We estimate:

$$
\Delta \text { Attitudes }_{c}=\beta_{0}+\beta_{1} \Delta \text { Fem.Empl } \cdot d+\varepsilon,
$$

where $\Delta$ Attitudes is the difference between the attitudes of East German "young” female cohorts (born after 1935) and those of "old" female cohorts (born before 1935) in county $c$. We use the change relative to the group of birth cohorts born before 1935 because, as shown in section A.I.viii the attitudes of those cohorts do not seem to have been affected by state socialism and therefore can arguably be considered as baseline attitudes for our purposes. ${ }^{25}$ The variable $\Delta$ Fem.Empl. is the change in the female employment rate between 1950 and 1985 in district $d$. We address the issue of endogeneity of $\Delta$ Fem.Empl.$_{d}$ by employing an IV strategy, in the spirit of Moretti (2013), in which the instrument for $\Delta$ Fem.Empl.d is defined as

$$
I V \equiv \sum_{s} \eta_{s d} \times \lambda_{s} \times \Delta E m p l_{s},
$$

where $\eta_{s d}$ is the share of all those employed, regardless of gender, in industry $s$ in district $d$ in $1950, \lambda_{s}$ is the share of women employed in industry $s$ nationwide in 1950 and $\Delta E \mathrm{mpl}_{._{S}}$ is the nationwide change between 1950 and 1985 in (log) employment in industry $s$. Because we use Census data for East Germany, district is the finest available geographical level (there are fourteen districts). The basic intuition behind the IV approach is the following: if employment in a relatively feminized industry increases nationally, districts

\footnotetext{
${ }^{25}$ In section A.I.viii, we show evidence on female attitudes toward work from a cohort analysis.
} 
Table 2.-Local Female Employment and AtTitudes

\begin{tabular}{|c|c|c|c|c|}
\hline & $\begin{array}{c}\text { OLS } \\
(1) \\
\Delta \text { Women's } \\
\text { Attitudes }\end{array}$ & $\begin{array}{c}\text { OLS } \\
(2) \\
\Delta \text { Female } \\
\text { Employment }\end{array}$ & $\begin{array}{c}\text { OLS } \\
(3) \\
\Delta \text { Women's } \\
\text { Attitudes }\end{array}$ & $\begin{array}{c}2 \text { SLS } \\
(4) \\
\Delta \text { Women's } \\
\text { Attitudes }\end{array}$ \\
\hline $\begin{array}{l}\Delta \text { Female } \\
\text { Employment }\end{array}$ & $\begin{array}{l}0.008 \\
(0.007) \\
(0.007) \\
{[0.332]}\end{array}$ & & & $\begin{array}{c}0.024 \\
(0.013)^{*} \\
(0.012)^{*} \\
{[0.152]}\end{array}$ \\
\hline IV & & $\begin{array}{l}82.966 \\
(13.853)^{* * *} \\
(33.375)^{* *} \\
{[0.046]^{* *}}\end{array}$ & $\begin{array}{l}1.967 \\
(1.046)^{*} \\
(0.694)^{* *} \\
{[0.126]}\end{array}$ & \\
\hline $\begin{array}{l}\text { Observations } \\
\text { Angrist-Pischke } \\
\text { F-statistic, } \\
\text { 1st stage }\end{array}$ & 60 & $\begin{array}{l}60 \\
6.18\end{array}$ & 60 & 60 \\
\hline
\end{tabular}

The table shows the output of OLS estimation of equation (3) (column 1), first-stage (column 2), reduced form (column 3), and two-stage least square (2SLS) estimation of equation (3) (column 4). Robust standard errors in parentheses (below: clustered, allowing for arbitrary correlations within districts; there are fourteen districts). We report in brackets the $p$-value obtained using the bootstrap procedure developed by Cameron et al. (2008). See section IIICi for details on IV construction. Significant at ${ }^{* * *} 1 \%$, ${ }^{* *}$, and ${ }^{*} 10 \%$.

where the industry employs a relatively large share of the labor force will experience a relatively large increase in female employment (Moretti, 2013).

Table 2 shows the output of the OLS estimation of equation (3) (column 1), the first-stage estimation (column 2), the reduced-form estimation (column 3), and two-stage least square (2SLS) estimation (column 4). The 2SLS estimate of $\beta_{1}$ is 0.024 , significant at the $10 \%$ level (SE equal to 0.013 ), suggesting a positive relationship between local female employment and attitudes. ${ }^{26}$ The coefficient on $\Delta$ Fem.Empl.d implies that a 1 percentage point increase in the female employment rate is associated with a 2.4 percentage point larger mean probability that women report success at work to be important. The 2SLS estimate is larger than the OLS estimate. In addition to measurement error in $\Delta \mathrm{Fem} . \mathrm{Empl} .{ }^{27}$ this could be due to the effect of local female employment being heterogeneous across counties. If there are indeed heterogeneous effects of $\Delta$ Fem.Empl. on $\triangle$ Attitudes, then consistent OLS estimates measure the average effect of $\Delta$ Fem.Empl. on $\Delta$ Attitudes across all counties. On the other hand 2SLS estimates the average effect for the counties that are marginal in terms of a change in female employment; they experience a relatively large change in female employment if and only if there exists an industry mix conducive to such change. ${ }^{28}$ If the effect of local female employment on attitudes is larger for counties that are marginal, the 2SLS estimates will ex-

\footnotetext{
${ }^{26}$ With district-clustered standard errors, the coefficient in the 2SLS regression is significant at the $10 \%$ level (SE equal to 0.012 ). When we bootstrap the standard errors following the procedure developed by Cameron, Gelbach, and Miller (2008), the p-value is 0.152 .

${ }^{27}$ For the 1950 period, data on female employment rate had to be imputed in the following way. The numerator is the number of women employed. For the denominator, ideally we would consider the number of workingage women. This statistic is not available for 1950. Therefore, we consider population data for 1955, when information on number of women by age is reported. We calculate the share of women aged 15 to 60 in 1955 and apply this share to the population numbers from 1950 .

${ }^{28}$ See Imbens and Angrist (1994) for a discussion. For a recent example, see Eisensee and Strömberg (2007).
}

ceed those of consistent OLS. In practice, however, the IV standard errors are quite large and prevent us from drawing definitive conclusions.

To summarize, these regressions should be interpreted cautiously because of data limitations. Setting this concern aside, the estimates suggest that the change in women's attitudes toward work was larger in areas where the change in female employment was larger. This suggestive evidence is consistent with the theoretical analysis by Fogli and Veldkamp (2011), who present a dynamic model of culture in which women have heterogeneous beliefs about the consequences of paid employment and these beliefs evolve due to intergenerational learning. Specifically, women learn about the long-run payoffs from employment by observing nearby working women, and their attitudes change over time as a consequence of this process.

The role of propaganda. We continue our examination of the potential channels of influence by analyzing the role of propaganda. East German women might have been affected by the regime's, propaganda to bring them into the labor force (see figure A.4 for an example; see also Kranz (2013). We explore this possibility by (a) employing individual-level proxies for ideology; (b) exploiting plausibly exogenous spatial variation in the availability of West German TV (Bursztyn \& Cantoni, 2015); and (c) exploiting plausibly exogenous variation in the time spent in school learning the foundations of the socialist system (Fuchs-Schündeln \& Masella, 2016). We provide a discussion of the estimation details and the results below. To summarize, we fail to reject the null hypothesis of no propaganda effect on attitudes, although when we use the second approach, the standard errors are quite large and prevent us from drawing definitive conclusions.

Approval of the regime and attitudes toward work. One may argue that women whose attitudes were shaped by the exposure to government propaganda are more favorable to the regime itself. Under this scenario, we should observe more positive attitudes toward work for East German women who are more in favor of the socialist regime. We explore this possibility by estimating (in the sample of East German female respondents to the GSOEP) the following equation:

$$
Y_{i}=\delta_{0}+\delta_{1} \text { Ideology }_{i}+\delta_{2} X_{i}+\varepsilon_{i},
$$

where $Y_{i}$ is the variable Job Success Important. Ideology is constructed using one of either two questions, asked in 1990 and 1992, respectively: how satisfied the respondent was with democracy in the GDR, and which political party the respondent supported. Specifically, the variable Ideology is either Satisfaction with Democracy, which takes a higher value the larger one's reported satisfaction with democracy in the GDR is, or the dummy variable Party Support, which takes a value of 1 if the respondent expresses support for the PDS (Party of Democratic Socialism), which was the successor of the SED (Socialist Unity Party of Germany), the ruling party in the GDR. $X_{i}$ is a full set of controls described in section A.I.v. The estimates of equation (5) are shown in 
columns 1 and 2 of table A.8: the coefficient estimate of $\delta_{1}$ is not significant in either specification. ${ }^{29}$

Exposure to West German TV and attitudes toward work. In our second approach, we use a measure of propaganda based on TV consumption during the divided years. ${ }^{30}$ In practice, we regard East Germans who used to live in counties not reached by the West Germany TV as more exposed to GDR propaganda. The main public TV networks from East Germany (DFF) began its broadcasts in 1952. "By that time very few East Germans owned a TV set. However, television gained popularity rapidly, and by the end of 1958, there were already over 300,000 TV sets in the GDR" (Bursztyn \& Cantoni, 2015, p. 8). East German TV was "a drab mixture of political propaganda and Soviet-produced movies" (Bursztyn \& Cantoni, 2015, p. 1). Under the assumption that encouragement of women's work was part of the East German TV propaganda, more positive attitudes toward work among women who were more exposed to the East German TV channels would be suggestive that propaganda is a plausible mechanism behind the evidence in the "Main Estimates" section. Unfortunately, we do not have information on the heterogeneous reception of national television in East Germany. ${ }^{31}$ We thus develop an indirect measure of heterogeneous exposure to East German TV, based on a notion of "crowding out" from the West German one. We contend that individuals who had access to West German TV arguably reduced the time spent watching the East German TV, since alternative sources of information and entertainment reached them. We thus presume that areas that did not receive the West German TV were relatively more exposed to East German propaganda. Therefore, comparing these areas to those receiving West German TV provides an indirect test of the effect of propaganda on women's attitudes toward work. We estimate the following regression (using the sample of East German female respondents to the GSOEP):

$$
Y_{i}=\gamma_{0}+\gamma_{1} \text { No West } T V_{c}+\gamma_{2} X_{i}+\varepsilon_{i},
$$

where the variable No West $T V_{c}$ is a dummy for lack of predicted reception of West German TV (based on a signal propagation model) in the individual's county of residence. No West $T V$ is built starting from the municipality-level measure used in Bursztyn and Cantoni's (2015) investigation of the effect of

\footnotetext{
${ }^{29}$ The standard error associated with the coefficient for Party Support is quite large, possibly reflecting the overall low level of approval of the PDS in the sample (2.7 percentage points). According to our estimates, supporting the PDS is associated with up to 11 percentage points higher likelihood or reporting that work is important; however, we cannot reject a negative association of up to 12 percentage points either. The point estimate for the coefficient Satisfaction with Democracy is more precise: according to our analysis, women who report a one-point-higher index of satisfaction with democracy in the GDR are at maximum 1 percentage points more likely to report that being successful at work is important to them.

${ }^{30} \mathrm{~A}$ large literature documents the effect of exposure to television on political (Gentzkow, 2006; Della Vigna \& Kaplan, 2007; Enikolopov, Petrova, \& Zhuravskaya, 2011; Della Vigna et al., 2014) and social (Jensen \& Oster, 2009; Olkean, 2009; La Ferrara, Chong, \& Duryea, 2012) outcomes.

${ }^{31}$ Bursztyn and Cantoni (2015) report data suggesting that access to national TV channels was spatially homogeneous in the GDR.
}

exposure to West German TV on the consumption behavior of East Germans. ${ }^{32}$ We first use their data of the West German TV signal in East German municipalities to calculate the weighted (by municipality area) average signal at the county level. We then follow their definition of treatment area by considering as not-receiving West German TV (No West TV) the counties whose average TV signal strength is lower than or equal to that of the city of Dresden. ${ }^{33}$ As a result, the following counties are classified as not receiving West German TV during the divided years: Bautzen, Dresden, Görlitz, Sächsische Schweiz-Osterzgebirge, Vorpommern-Greifswald, and Vorpommern-Rügen.

The estimates show a positive and significant coefficient on No West $T V$ in a regression where the dependent variable is the measure of East German women's attitudes toward work (column 3 of table A.8). However, since the areas that did not receive the West TV signal are in the northeast and southeast regions of the former GDR, the estimated coefficient for No West TV in equation (6) is likely biased due to spurious correlation with distance from the border. ${ }^{34}$ Following Bursztyn and Cantoni (2015), we augment equation (6), adding Distance ${ }_{c}$, as defined in the "Main Estimates" section as a control; the coefficient on No West TV is substantially reduced, and it is no longer statistically significant (column 4 of table A.8). A concern arises from the possibility that once the control for distance is added, not enough identifying variation is left to estimate the relation between the exposure to West German TV and attitudes. In other words, since Distance and No West $T V$ are highly correlated, if they both have an impact on attitudes, the effect of differential exposure to West TV might be hard to detect, once distance is controlled for, given that No West TV is more likely to be measured with error than Distance. ${ }^{35}$ To explore this possibility, we restrict the analysis to women who lived farther than $100 \mathrm{~km}$ from the border. While in the original sample, $88 \%$ of women received West $\mathrm{TV}$, and $12 \%$ did not, in this restricted sample, $72 \%$ of women received West TV and 28\% do not. In practice, although the gap in distance between the "treated" and "control" units is reduced in this sample, there is still substantial variation in treatment status. Nevertheless, the coefficient on No West TV

\footnotetext{
${ }^{32}$ Bursztyn and Cantoni (2015) use a signal propagation model to predict the availability of West German television in the GDR as follows. First, they measure the TV signal for the whole territory of the former GDR, divided into a $1 \times 1$ raster. Based on this raster, they then calculate the level of TV signal strength for each municipality. See their paper for a more detailed description of the measure of TV signal strength.

${ }^{33}$ Ideally, one wants to classify municipalities based on a dummy variable for receiving the signal or not. However, as Bursztyn and Cantoni (2015) point out, the discontinuity of TV signal strength is fuzzy. They thus use the anecdotal evidence that Dresden was close to the signal discontinuity and define a municipality as not receiving any West German TV if it had a signal strength weaker than or equal to that in Dresden.

${ }^{34}$ See Bursztyn and Cantoni (2015) for a map of the predicted West German TV signal in East Germany.

${ }^{35}$ That distance from the border might have predictive power is confirmed by the fact that in a regression of attitudes on distance and control variables in the sample of women who live in the part of East Germany receiving West television, the coefficient of distance is positive and statistically significant at the $10 \%$ level.
} 
is smaller than that in the baseline sample and statistically insignificant (column 5 of table A.8). This suggests that the relation between exposure to West German TV and attitudes is due to spurious correlation with distance from the border.

Overall, the results of this analysis suggest that once distance from the inner border is properly taken into account, there is no evidence of more positive attitudes toward work among East German women who were relatively more exposed to East German television. However, the standard errors are quite large and prevent us from drawing definitive conclusions. $^{36}$

Learning the foundations of the socialist system. One of the official purposes of the compulsory schooling system in the GDR was the formation of a socialist personality; every school subject was shaped by this goal (Fuchs-Schündeln \& Masella, 2016). Furthermore, two subjects in compulsory school were specifically aimed at teaching the foundation of the socialist system: Social Studies and Introduction to Socialist Production (Fuchs-Schündeln \& Masella, 2016). This education system was quickly dismantled after the fall of the Berlin Wall, and any reference to the formation of a socialist personality was eliminated from school subjects (FuchsSchündeln \& Masella, 2016). Conversely, the school system in West Germany remained unchanged throughout the transition. Following the strategy in Fuchs-Schündeln \& Masella (2016), we compare attitudes toward work between students who spent different amounts of time in socialist schools for arguably exogenous reasons. Under the assumption that the longer the time spent in socialist education, the larger the exposure to the regime propaganda, we interpret this comparison as an additional test of the role that propaganda played in shaping attitudes toward work. Specifically, we exploit the fact that at the time of the transition, students of the same birth cohort had been exposed to different amounts of socialist education depending on their month of birth. In the GDR, children who turned 6 on or before May 31 started first grade in September of the same year; students of the same birth cohort who were born after May 31 started first grade the following year. Therefore, among the children of schooling age during the transition, those born on or before May 31 had spent one more year exposed to socialist education than children in their same birth cohort born on or after June.

We estimate the following equation:

$$
\begin{aligned}
Y_{i c}= & \theta_{0}+\theta_{1} \text { East }_{i c}+\theta_{2} \text { Before May 31st } t_{i c} \\
& +\beta_{3}(\text { Before May 31st X East })_{i c}+x_{i c}+\gamma_{c}+\epsilon_{i c},
\end{aligned}
$$

where $Y_{i c}$ is our measure of attitudes toward work for woman $i$ in birth cohort $c$, and East ${ }_{i c}$ indicates whether a female respondent lived in East Germany before the fall of the Berlin Wall. Before May $31 s t_{i c}$ is a dummy for being born on or

\footnotetext{
${ }^{36}$ Specifically, we cannot reject that not receiving West German TV made East German women more likely to report that work is important by up to 7 percentage points, and less likely by up to 3 percentage points
}

before May 31. We pool several survey years together and estimate equation (7) using a sample of 2,951 women who answered the question of interest between 1990 and 2012 and who belong to the birth cohorts 1974 to $1983 .{ }^{37}$ These women were in grades 1 to 10 in November 1989 when the transition to the new school system started. Within each birth cohort $c$, women born before May 31 had spent one more year in socialist education than their peers born on or after June 1. Our term of interest is Before May 31st x East ${ }_{i c}$, a difference-indifference parameter. Equation (7) estimates the causal effect of one more year of socialist education by comparing the difference in attitudes between East German women within the same birth cohort and born before or after May 31, versus the same difference for West German women. ${ }^{38}$

The results of this analysis, shown in table A.9, do not suggest that women who were more exposed to a socialist education have more positive attitudes toward work. ${ }^{39}$

\section{Validity and robustness.}

Attitudes in 1992. As discussed in section IIIA, a potential concern is that the estimated difference in responses between East and West Germany might be caused by the slightly different phrasing of the question that they answered. Fortunately, the GSOEP also interviewed survey respondents regarding their attitudes toward work in 1992 using the same wording for the question in East and West Germany. The question is the same as the are asked in West Germany in 1990: "Different individuals find different things in life important. How important are the following things to you today? Succeed in one's occupation." In table A.10 we show the estimates

\footnotetext{
${ }^{37}$ Information on month of birth is available for about $90 \%$ of the survey respondents in the relevant years. Notice that unlike the analysis in table A.8, where we use data from the earliest year when the relevant information is available (1990 or 1992), in this part of the analysis we study women who answer the GSOEP in any year between 1990 and 2012; this is because most of the women born between 1974 and 1983 participate only in the most recent waves of the GSOEP, given their young age. Notice that we find that the East-West difference in attitudes persists until the last year when the question of interest is asked in the GSOEP, 2012 (see the "Main Estimates" section).

${ }^{38}$ We do not estimate equation (7) with a spatial RD because most of the women born between 1974 and 1983 participate only in the most recent waves of the GSOEP, given their relatively young age. Therefore, we cannot reliably infer their county of residence during the separated years. See later in this section for a discussion of measurement error in the running variable for survey respondents observed in more recent years. Furthermore, notice that the underlying identifying assumption for the causal estimation of the parameter of interest $\beta_{3}$ in equation (7) is arguably stringent enough. In practice, it is required that any spurious (i.e., independent of socialist education) difference in attitudes between individuals from the same cohort who start their first grade at different ages is comparable between East and West Germany.

${ }^{39}$ The controls in columns 2 and 3 are a full set of age dummies, state fixed effects, and month of birth (entered linearly), and are selected following Fuchs-Schündeln \& Masella (2016).

Specifically, in the sample used in this part of the analysis, East German women who were born after May 31 appear 7 percentage points more likely to report that success at work is important to them than their West counterparts; among their peers born before May 31, this difference might be a maximum 5 percentage point, larger, but it might also be 7 percentage point, smaller, and the difference between these two groups is not statistically significant.
} 
from the sample of individuals interviewed in 1992 who were also interviewed in $1990,{ }^{40}$ using the answers to the question posed in 1992 as the dependent variable. The results using this sample and dependent variable confirm the results from table I (that uses the 1990 survey responses). Estimates are very similar when we measure attitudes in subsequent years, when the same question is asked again to East and West Germans (results are discussed in the "Long-Term Analysis" section).

East-West migration during the divided years. Around 3 million people migrated from the East to the West before the erection of the Berlin Wall in $1961 .^{41}$ From 1961 to the end of 1988, around 600,000 people emigrated from the GDR to the FRG. ${ }^{42}$ In contrast, about 30,000 individuals per year emigrated from the FRG to the GDR in the 1950s, and almost none emigrated after the Berlin Wall was built (Fassmann \& Münz, 1994). This migration creates an identification challenge in our context. If the distributions of female attitudes toward work were similar in the East and the West at the time of the separation, but women attaching less importance to job success migrated from the GDR to the FRG, then this could be driving our main finding from the "Main Estimates" section. To test for this, we restrict the sample to women who lived in the East in 1949, the and create two dummy variables, "Moved E to W 49-56" and "Moved E to W 57-89." These dummies take on a value of 1 if a woman migrated from the East to the West from 1949 to 1956 or from 1957 to 1989 , respectively. ${ }^{43}$ The coefficients on the two dummies in a regression with Job Success Important as the dependent variable capture the attitudes of women who migrated East-West relatively early or relatively late, respectively, with respect to

\footnotetext{
${ }^{40}$ The GSOEP tracks individuals over time. However, a certain number of respondents are also added at each wave, and some individuals are not followed over time due to attrition. We retain only individuals who responded in 1990 for two reasons. First, since we use the county of residence at the time of the first interview to infer the county of residence during the separated years, the degree of error induced by this procedure is higher for individuals who are first interviewed in 1992. Second, we want to replicate as closely as possible a situation in which the individuals whose answers we use in table 1 are asked a question with the same exact wording in East and West, in order to gauge to what extent the estimates in table 1 are affected by the different wording in 1990 . Notice, however, that the estimates are substantially unchanged when all the individuals who answer in 1992 are considered (see table A.13, column 1).

${ }^{41}$ This number represents a significant share of the peak population (of around 19 million) living in the Soviet-controlled territory in 1947 that officially became the GDR in 1949.

${ }^{42}$ Family reunions and general economic reasons were the two chief motives for migration during the divided years. See Alesina et al. (2007) for a discussion and references.

${ }^{43}$ We select 1957 because this year divides the distribution of East to West female migrants approximately into two halves. We classify a woman as having moved from east to west if (a) she is currently in West Germanyshe is in the West German sample; (b) area of origin is former GDRthe question asks whether one is originally from the former GDR, former German territory, or other; (c) reports having lived in West Germany since after 1949 (so we do not capture movers before separation) - the question asks whether she moved before 1949 or after. Then we divide the sample into pre-1956 and post-1956 a movers using a question that asks, "Lives in West Germany since ... (Year)." After 1961, as a consequence of the building of the Berlin Wall, there was a significant change in migration possibilities. This suggests using 1961 to split the sample. Unfortunately, only five women moved after 1961, preventing us from further analysis.
}

women who stayed in East Germany. As the regression estimates in table A.11, column 1 show, women who migrated East to West during the divided years attach significantly less importance to job success. ${ }^{44}$ To address the potential issue signaled by this finding, we code the women who moved from East to West as if they lived in East Germany in 1989. This is in the spirit of "restoring" the distribution of preferences in the GDR as if migration had not occurred. On this "manipulated" sample, we then estimate the main relation of interest between politico-economic regimes and attitudes toward work. ${ }^{45}$ We perform this exercise in the remaining part of table A.11. In column 2, for comparison, we report OLS estimates on the entire sample of women in the GSOEP (i.e., women observed in East and West in 1990). In column 3, we operate the "manipulation" in order to address selective migration. The coefficient estimates in columns 2 and 3 are very similar indicating that our main finding from the "Main Estimates" section is not explained by East-West migration during the divided years. ${ }^{46}$

Long-term analysis. We have shown significant differences in the attitudes of East and West German respondents two years after the reunification. In this section, we consider every year when a question about the importance of career success is asked in the GSOEP and investigate whether the differences between East and West Germany persist in the longer term. We use two approaches. First, we estimate the OLS and the spatial RD models, following over time respondents who answered the question of interest in 1990. We exclude respondents who joined the GSOEP in waves following that of 1990, for whom the county of residence during separation can be inferred less reliably. ${ }^{47}$ For the individuals in the estimation sample, residence is kept constant at the 1990 observation. Tables A.12 and A.14 show the estimates for attitudes and employment, respectively. ${ }^{48}$ While the overall picture suggests that women in the East have relatively more

\footnotetext{
${ }^{44}$ East-West female migrants might attach less importance to job success than stayers for two (nonmutually exclusive) reasons: self-selection and differential treatment. For the latter explanation, recall from section A.I.i that the FRG encouraged a system in which women stayed home after they had children or went back to part-time employment after an extended break. East-West female migrants were exposed to the West Germany system, which may have negatively affected their attitudes toward work. At the same time, the reference group was exposed to the GDR regime that positively affected their attitudes toward work.

${ }^{45}$ Notice that we cannot execute a spatial RD in this context, since we do not know the (old) county of residence in East Germany of individuals who had moved to West Germany by 1990 .

${ }^{46}$ In section A.I.vii we present further sensitivity analysis. Specifically, the section analyzes alternative specifications, nonrandom selection just East/West of the border, and placebo borders.

${ }^{47}$ See note 40 and section A.I.iii for further discussion of measurement error.

${ }^{48}$ Notice that in section A.I.iv, we use employment data for the period 1950-1990 and show that women's participation in the formal labor market was higher in East than in West Germany, and employed women in the East worked longer hours. The change in this dimension was arguably one of the very few positive achievements of the East German regime. We also estimate equation (2), with employment status in 1990 as the dependent variable, and find evidence that confirms the historical accounts.
} 
positive attitudes toward work and are relatively more likely to be employed than women in the West in the long term, the standard errors tend to be large in the latest years that we consider as the sample size shrinks. In the second approach, we estimate the OLS model using the entire sample of GSOEP respondents. ${ }^{49}$ The results from this second approach, shown in tables A.13 and A.15, point toward a persistent effect of the exposure to different regimes on both attitudes and employment. In each of the years studied, until the last year for which the information is available (2012), German women report less positive attitudes toward work and are less likely to be employed than men; however, this gender gap is significantly lower for individuals who in 1989 lived in East versus West Germany.

Gender-role attitudes. We perform a comparison of gender-role attitudes in East and West Germany for women and men using data from the German General Social Survey (ALLBUS). ALLBUS is the German equivalent of the U.S. General Social Survey and currently covers the years 1980 to 2012 at a biannual cadence. We use answers to six questions (examined separately) that specifically, ask, for the degree of agreement with the following statements: (a) "A working mother can just as well have a hearty and trustful relationship with her children as a non working mother." ${ }^{50}$ (b) "Certainly, a baby suffers if his or her mother is employed." (c) "It is even good for a child if his or her mother is employed instead of merely focusing on household work." (d) "It is more important for a woman to support her husband's career instead of making her own career." (e) "It is better for all if the husband works and the wife stays at home taking care of the household and the children." (f) "A married woman should turn a job down if only a limited number of jobs is available and her husband is able to make a living for the family." ${ }^{51} \mathrm{We}$ use restricted-access information on the individual's place of residence at the time of the interview. ${ }^{52}$

\footnotetext{
${ }^{49}$ In practice, we remove the restriction that the respondent had to answer the question of interest in 1990. When we estimate the OLS model, we are not worried about measurement error in inferring the county of residence during the divided years since we do not use such information. Notice that as for the 1990 data, we only use individuals from the GSOEP samples who are representative of the German population (i.e., samples A, B, E, and H)

${ }^{50}$ Recall that the GDR government took initiatives to facilitate the combination of employment and family responsibilities.

${ }^{51}$ The respondents can give one of the following answers: "Completely agree," "Tend to agree," "Tend to disagree," "Completely disagree," "Don't know." As we did above in constructing the variable Job Success Important, we obtain six measures of gender role attitudes by grouping in a unique category, respectively, the two levels of agreement and the two levels of disagreement, which we recode as 0 and 1 , in such a way that each 1 represents the less traditional view and 0 the more traditional one.

${ }^{52}$ The ALLBUS data sets used for our analysis contain detailed regional information and are accessible at the Secure Data Center (www.gesis.org/ en/sdc) of the GESIS Data Archive for Social Sciences in Cologne Germany. Researchers are required to sign a special usage agreement and to work within an individually tailored secure virtual workspace. See GESISLeibniz Institute for the Social Sciences (2013) and GESIS-Leibniz Institut für Sozialwissenschaften (2014) for details.
}

The first year when we can analyze ALLBUS data on gender-role attitudes is $1996 .{ }^{53}$ This might be problematic for two reasons. First, we think that it is important to examine differences in attitudes between East and West Germans by 1990 in order to distinguish the effect of socialism from that of postsocialism. Second, we are able to recover the place of residence of each respondent only in the year of the interview; therefore, both the dummy East and the variable Distance from equation (2) are measured with error if the interviewee changed place of residence with respect to the divided years. Nevertheless, we think that it is interesting to investigate the extent to which the emerging pattern using the GSOEP data is confirmed when looking at gender-role attitudes and female attitudes toward work.

Using the 1996 wave of ALLBUS, we reestimate equation (2), with the dependent variable being the answer to each of the six questions listed in section IIIA. A positive coefficient for East in equation (2) would signal less traditional genderrole attitudes in East versus West Germany. Since we use both men and women for this analysis, we augment equation (2) with a control for the gender of the respondent. ${ }^{54}$

The results of the analysis are reported in table A.17. For each question, we show the coefficient for East across different bandwidths. Figure A.6 allows a visualization of the unconditional differences between East and West Germans at the border (i.e., without controls for border segment fixed effects and gender).

The emerging picture points toward an effect of the regime on gender-role attitudes for both women and men (for the estimates disaggregated by gender, see table A.18; table A.19 also shows estimates of a difference-in-differences model that compares women and men on the two sides of the border). In particular, when we consider questions regarding the effect of a mother's work outside the home on her children's well-being, East Germans are unequivocally less traditional than West Germans. Regarding questions about the appropriateness of specialization of roles between men and women, the picture is somewhat more mixed. East Germans are significantly less likely to believe that the husband should work outside the home, whereas the woman should take care of the house and children. However, there is no significant difference (except for the OLS estimates in table A.19) in the level of agreement with the statements that a wife should support her husband's career more than her own and that she should turn down jobs when few of them are available. This lack of difference masks a positive, although not precisely estimated, coefficient among women and a negative imprecise coefficient for men. Given that there exists an unemployment rate gradient along the border after reunification (see

\footnotetext{
${ }^{53}$ This is because the information on the individual respondent's county of residence, which is needed to implement the spatial $\mathrm{RD}$, is available only starting from the 1994 wave of ALLBUS, and the first year after 1994 when the gender-role attitudes questions are asked in the survey is 1996.

${ }^{54}$ We expect the differences between the GDR and the FRG in terms of focus on women's economic inclusion to have affected the gender-role attitudes of both women and men.
} 
Fuchs-Schündeln \& Izem, 2012), one could speculate that the relatively high level of unemployment faced by East German men in 1996 might in part explain these results. This suggests that it may indeed be important to distinguish the effect of socialism from that of postsocialism on individual attitudes.

\section{Comparison of CEECs and WECs}

In this section we broaden our focus to state socialism throughout the entire Central and Eastern European region. Specifically, this section presents our diff-in-diff analysis that compares gender-role attitudes formed in CEECs and WECs, before and after the imposition of state socialism in CEECs. The institutional background is discussed in detail in section A.II.i.

\section{A. Measurement and Data}

In order to implement our diff-in-diff analysis, we need to observe individuals in both CEECs and WECs before and after the establishment of state socialist regimes in CEECs. This is problematic because the 1980s are the earliest years in which a measure of gender-role attitudes in cross-country surveys is available, long after the imposition of state socialist regimes in CEECs. We cope with this challenge by using the gender-role attitudes of U.S. immigrants and their offspring to construct a time-varying measure of attitudes in their source country, in the spirit of Algan and Cahuc (2010). Our source of information about gender-role attitudes is the General Social Survey database (GSS), which collects responses from U.S. residents between 1972 and 2016 and contains individual data on the respondent's country of birth and that of her ancestors since 1977. The GSS question on the country of origin reads: "From what countries or part of the world did your ancestors come?" The individual can list up to three countries by order of preference. ${ }^{55} \mathrm{We}$ select the country of origin which the individual ranks highest. ${ }^{56}$

The CEECs in our sample are Czechoslovakia, Hungary, Lithuania, Poland, and Romania. The Soviet Union exercised a major influence in these five countries starting from the end of World War II. Prior to the end of the War, Lithuania had been incorporated into the Soviet Union. ${ }^{57}$ In the four other countries Stalin favored a system of "indirect rule through national communist elites" (Mazower, 2009, p. 282). State socialist regimes were imposed, with the Soviet hold over them ultimately consolidated in the formation of the War-

\footnotetext{
${ }^{55}$ Around two respondents out of three list only one country.

${ }^{56}$ We include only countries for which we can construct a time-varying measure of attitudes for both the periods before and after 1945. This excludes Switzerland since we cannot construct a measure for the post-1945 period.

${ }^{57}$ Lithuania was first incorporated into the Soviet Union in July 1940, but was under German occupation between June 1941 and July 1944. See Misiunas and Taagepera (1993) for a discussion of Lithuania under Soviet rule.
}

saw Pact (McMahon, 2003). (See section A.II.v for a discussion of some background to the imposition of Soviet rule in CEECs, and section A.II.v for an explanation as to why our sample does not include other countries located in the region.) The WECs in our sample are: Austria, Belgium, Denmark, Finland, France, Greece, Ireland, Italy, Netherlands, Norway, Portugal, Spain, Sweden, and the United Kingdom Table A.21 reports the count of immigrants from each of the nineteen countries in our sample.

GSS respondents are asked if they were born in the United States and how many of their parents and grandparents were born in the United States. These responses allow us to separate responders into four potential groups of immigrants: fourth-generation Americans and above (more than two grandparents born in the United States and both parents born in the country) ${ }^{58}$; third-generation Americans (at least two grandparents born outside the United States and both parents born in the country); second-generation Americans (at least one parent immigrated to the United States); and first-generation Americans. ${ }^{59}$

Gender-role attitudes are measured by the following question: Please tell me whether you strongly agree, agree, disagree, or strongly disagree with the following statement. It is much better for everyone involved if the man is the achiever outside the home and the woman takes care of home and family." ${ }^{60}$ We recode the answers, "Strongly Agree," "Agree," "Don't Know," "Disagree," and "Strongly Disagree," as respectively, 1, 2, 2.5, 3, and $4 .{ }^{61}$ We call the resulting index "Better for Man to Work, Woman Tend Home"; the higher its value, the less traditional are an individual's attitudes toward women working. Section A.II.iv describes in detail how we track the change over time in gender-role attitudes using the GSS.

\section{B. Empirical Strategy}

The imposition of state socialist regimes in CEECs arguably constitutes a quasi-experimental setting. Therefore, in principle, the before-after difference in attitudes (where "after" means "following the imposition of state socialism") could be interpreted as the effect of the regime. A concern

\footnotetext{
${ }^{58}$ For simplicity, in most of the text we refer to this group as "fourthgeneration Americans."

${ }^{59}$ We depart from Algan and Cahuc (2010) by adding first-generation immigrants to the sample, while at the same time always controlling for generation dummies in our regressions where the outcome of interest is the gender-role attitude of U.S. immigrant $i$. We include responses of firstgeneration immigrants to obtain the maximum number of observations on gender-role attitudes. However, our results still hold when we drop firstgeneration Americans.

${ }^{60}$ Among the GSS questions about gender roles, this is the only one that features at least thirty responses for CEECs after 1945 (49 responses).

${ }^{61}$ Only 147 out of 8,846 respondents answer "Don't Know". Results are similar if we use alternative approaches, such as recoding "Don't Know" as missing, and recoding the answers "Strongly Agree," "Agree," "Don't Know," "Disagree," and "Strongly Disagree" as, respectively, 1, 2, 3, 4, and 5 .
} 
arises, however, that a general trend in gender attitudes might have already been in place. We estimate a diff-in-diff equation, where we compare the evolution of attitudes in CEECs versus WECs.

The regression equation that forms the basis of our empirical analysis is

$$
\begin{aligned}
Y_{\text {igrcp }}= & \beta_{0}+\beta_{1} \text { CEEC } C_{c}+\beta_{2} \text { Post } 1945_{p}+\beta_{\text {DiD }} \text { CEEC } C_{c} \\
& \times \text { Post } 1945_{p}+\beta_{4} X_{\text {icrp }}+\rho_{g}+\eta_{r}+\epsilon_{\text {igrcp }},
\end{aligned}
$$

where $Y_{\text {igrcp }}$ is the answer to the question "Better for Man to Work, Woman Tend Home" of individual $i$, belonging to generation $g$, residing in U.S. region $r$, who migrated (or whose ancestors migrated) from country $c$ in period $p$ (either before 1945 or between 1945 and 1990); $C E E C_{c}$ is a dummy taking the value of 1 if country $c$ belongs to the group of CEECs; Post $1945_{p}$ is a dummy taking the value of 1 if the individual's attitudes were formed in the country of origin between 1945 and 1990 (or inherited from someone whose attitudes were formed in the country of origin between 1945 and 1990); $\rho_{g}$ and $\eta_{r}$ are generational and regional dummies, respectively; and $X_{i}$ are individual-level characteristics. ${ }^{62} \mathrm{We}$ estimate both OLS and within-country (of origin) specifications of equation (8). For the baseline specification, we include only gender in $X_{i}$ because the politico-economic regime may have affected some demographics, resulting in their being outcome variables and thus "bad" controls. However, we also present estimates that include a rich set of individual characteristics. ${ }^{63}$

Identifying assumptions. Parallel trend assumption. The first identifying assumption in our context is that absent the state socialist regime, the evolution of gender attitudes in CEECs would have followed a path that cannot, on average, be distinguished from that in WECs. In table A.26, we provide evidence in support of the parallel trends assumption by estimating equation (8) using 1900 as the date of the imposition of state socialist regimes in CEECs rather than the true date of 1945. In column 1, the point estimate for the coefficient on CEEC $\times$ Post 1900 is positive but not significant. In column 2 (where we include additional controls), the estimate is negative and not significant. Overall, the evidence suggests that prior to the imposition of the new political and economic regime, gender-role attitudes in CEECs and the WECs evolved in a similar fashion. ${ }^{64}$

\footnotetext{
${ }^{62}$ Results are very similar if we allow the coefficients on the regional dummies to vary by period.

${ }^{63}$ In particular, the inclusion of this rich set of controls attempts to address concerns of bias arising from differential immigrants selection.

${ }^{64}$ In section A.II.iii, we further compare CEECs and WECs in terms of economic development and demographics and document that there are not systematically different changes in these variables over the period of interest, which would undermine our ability to identify the state socialism effect.
}

Selection of immigrants. Since we use the attitudes of immigrants, there is an additional identifying assumption: that the selection of immigrants on unobservables does not change differentially in CEECs and WECs after 1945 in a way that may affect gender-role attitudes. In our context, a concern of differential selection arises because the individual incentives for migrating from CEECs into the United States were likely to be different before and after $1945 .{ }^{65}$ To explore this possibility, we investigate the extent of differential selection on a rich set of observable variables. This should arguably help us infer something regarding the degree of differential selection on unobservables. Section A.II.ix discusses the estimation details and the results. Overall, the rather limited degree of selection on observables arguably supports the validity of our empirical strategy, though we acknowledge that our test is quite indirect and prevents us from drawing more definitive conclusions. Regarding the documented change in political views, this may reflect a direct treatment effect of state socialism rather than differential selection (Alesina \& Fuchs-Schundeln, 2007). Furthermore, we will show that estimates of our coefficient of interest in the main regression equation are qualitatively similar when we control for this rich set of individual characteristics.

\section{Diff-in-Diff Estimates}

Estimates of equation (8) are shown in table 3. The standard errors are clustered at country-period level (38 clusters). Our baseline estimates in column 1 suggest that attitudes formed in CEECs between 1945 and 1990 are less traditional than those formed in WECs during the same period. In column 2 , we include many individual controls: age, education, marital status, income, satisfaction with the financial situation of the household, employment status, number of children, mother's and father's education, religion, and political views. In columns 3 and 4, the post- 1945 period is restricted to 1945 to 1967 . Specifically, in these two columns, the sample is formed exclusively by immigrants who left Europe before 1967 and their descendants. The motivation for such specification is twofold. First, the interval 1945 to 1967 is interesting because state socialist governments throughout the region made the most efforts to promote women's economic inclusion during this period. Second, we want to consider a shorter interval for the "post" period so that the likelihood of shocks that may drive our results is smaller; in this specification, shocks to CEECs in the period 1968 to 1990 cannot bias the estimates. The estimates in columns 3 and 4 are very similar to those in columns 1 and 2. In summary, across columns 1 to 4 , the estimated coefficients on CEEC $\times$ Post 1945 imply that state socialism appears to decrease the degree of approval with the statement "Better for Man to Work, Woman Tend

\footnotetext{
${ }^{65}$ Section A.II.viii provides descriptive statistics and some background to migration patterns from countries in our sample to the United States over the period of analysis.
} 
TAble 3.-State Socialism and Attitudes toward Gender Roles, DifF-IN-DifF Estimation: DisAgreEMENT With "BetTER For MAN to Work, WOMAN TEND HOME"

\begin{tabular}{lcccc}
\hline \hline & & & \multicolumn{2}{c}{ Post-1945: 1945-1967 } \\
\cline { 4 - 5 } & $(1)$ & $(2)$ & $(3)$ & $(4)$ \\
\hline CEEC & $0.126^{* * *}$ & $0.097^{* * *}$ & $0.127^{* * *}$ & $0.095^{* * *}$ \\
& $(0.027)$ & $(0.025)$ & $(0.027)$ & $(0.025)$ \\
Post-1945 & $0.439^{* * *}$ & -0.020 & $0.451^{* * *}$ & -0.013 \\
& $(0.046)$ & $(0.047)$ & $(0.045)$ & $(0.038)$ \\
CEEC $\times$ Post-1945 & $0.175^{*}$ & $0.265^{* *}$ & $0.205^{*}$ & $0.281^{* *}$ \\
& $(0.103)$ & $(0.111)$ & $(0.108)$ & $(0.129)$ \\
Male & $-0.156^{* * *}$ & $-0.220^{* * *}$ & $-0.157^{* * *}$ & $-0.222^{* * *}$ \\
& $(0.014)$ & $(0.017)$ & $(0.015)$ & $(0.017)$ \\
Observations & 9,302 & 6,387 & 9,150 & 6,297 \\
Additional controls & No & Yes & No & Yes \\
Adjusted $R^{2}$ & 0.048 & 0.230 & 0.049 & 0.232 \\
Mean $y$ control & 2.706 & 2.760 & 2.707 & 2.760 \\
SD y control & 0.840 & 0.833 & 0.841 & 0.834 \\
\hline
\end{tabular}

This table reports estimates of equation (8), the main estimates for our comparison of CEECs and WECs. In columns 3 and 4, the "post-1945" period is restricted to 1945-1967; for this the sample period includes first-generation immigrants who left Europe between 1945 and 1967 and their descendants. Gender-role attitudes are measured by the following question: "Please tell me whether you strongly agree, agree, disagree, or strongly disagree with the following statement. It is much better for everyone involved if the man is the achiever outside the home and the woman takes care of home and family." We recode the answers to this question, "Strongly Agree," "Agree, "Don't Know," "Disagree," and "Strongly Disagree" as, respectively, 1, 2, 2.5, 3, and 4. Reference group in columns 2 and 4: nonreligious. Estimation method: OLS. Standard errors clustered at country-period level in parentheses. Regional and generation dummie always included. Number of countries is equal to nineteen. Additional controls: Age, Age squared, Education (yrs), Married, Household Income (categ), Satisfied with financial situation, Employed, Children, Mother's Education, Father's Education, Catholic, Protestant, Jew, Orthodox, Other Religion, Politically Mother's Education, Father's Education, Catholic, Protestat
Conservative. Significant at $1 \% \%^{* * *}, 5 \%$, and $10 \% *$

Home"; the mean of the point estimates is 0.23 . This compares to a mean of the index "Better for Man to Work, Woman Tend Home" of 2.73 in the control group of WECs. As a robustness check, we estimate the four specifications in table 3 , dropping individuals from one of the five state socialist countries at a time in order to check that no particular country is driving the results. The estimates (shown in table A.35) are qualitatively similar to the ones for the full sample of individuals. In interpreting our estimates, it is important to highlight that we estimate the effect of state socialism on gender-role attitudes relative to the effect of any other policy regime in place in Europe during the same period. While some Western governments, especially in the 1970s, embraced change in women's opportunities as a formal policy objective, ${ }^{66}$ in no case have their commitments been as long-standing as those of the governments in CEECs (Wolchik, 1981). (See section A.II.vii for more details.)

Since country of origin is an important determinant of gender-role attitudes (table A.24), our estimates may be affected by the changing composition of the population of immigrants over time in terms of country of origin. To investigate this issue, in table A.29, we report within-country

\footnotetext{
${ }^{66}$ Boschini, Gunnarsson, and Roine (2017), for instance, report that Sweden took some of its most important steps toward promoting gender equality in the early 1970s. They list, among these steps, the passage of a law that made it compulsory for married couples to file taxes separately, the recognition of the possibility for mothers and fathers to share parental allowances upon childbirth, and the extended provision of child care services. They also observe that such laws were followed by a rapid increase in female labor force participation, although predominantly in part-time jobs.
}

estimates of equation (8), which compare the evolution of attitudes in a given country versus that in other countries, and find similar results.

We also estimate, after constructing a 1900 cohort, a version of equation (8) where "Better for Man to Work, Woman Tend Home" is regressed on the baseline controls (generation dummies, regional dummies, and gender) plus country dummies and cohort indicators. Figure A.7 visually shows the estimates. The displayed coefficients on the cohort dummies indicate mean attitudes for CEECs and WECs relative to the 1945 cohort. Consistent with table A.26, the figure shows that before 1945, the attitudes in CEECs appear to have evolved similar to attitudes in WECs. ${ }^{67}$ Consistent with Table A.29, the figure suggests that after 1945, gender-role attitudes formed in CEECs during the state socialist regime become less traditional compared to WECs. ${ }^{68}$

Finally, we estimate equation (8) with employment status as the dependent variable and show that CEEC $\times$ Post 1945 has positive significant explanatory power (see section A.II.xii).

\section{Conclusion}

To what extent are attitudes affected by political regimes and government policies? In this paper, we focus on women's attitudes toward work and gender-role attitudes in the population at large, which have been shown to have significant effects on labor market outcomes. We exploit the imposition of state socialist regimes across Central and Eastern Europe and their efforts to promote women's economic inclusion for both instrumental and ideological reasons. In the main part of our analysis, we take advantage of the German partition into East and West after 1945. We find more positive attitudes toward work in the sample of East German women. Furthermore, we show suggestive evidence that the change in women's attitudes toward work was larger in areas where the growth in women's employment was larger, while we fail to reject the null hypothesis of no propaganda effect. Finally, we employ a difference-in-differences strategy that compares attitudes formed in Central and Eastern European countries (CEECs) and Western European countries (WECs) before and after the imposition of state socialism in CEECs. Gender-role attitudes formed in CEECs during the state socialist period appear to be significantly less traditional than those formed

\footnotetext{
${ }^{67}$ Since families of immigrants in the 1945 cohort have on average spent a longer time in the United States than those of immigrants in the 1990 cohort, a competing explanation for the pattern observed in the graph could be the adaptation of immigrants to the norms of the new society in which they live. In other words, it could be that attitudes in the two groups were similar in 1945 and 1990, but the process of cultural integration is completed only for the 1945 cohort. However, table A.24 (discussed in section A.II.vii) suggests this explanation is not likely given that the coefficients of the country effects in the regression with inherited attitudes in 1945 as dependent variable are statistically highly significant.

${ }^{68}$ In section A.II.xi, we provide a discussion of the relationship between shifts in gender-role attitudes and economic growth. In section A.II.x we show evidence from WVS on gender-role attitudes after 1990.
} 
in WECs. Overall, we overcome previous identification and data limitations and find that attitudes are profoundly affected by politico-economic regimes.

\section{REFERENCES}

Aghion, Philippe, Yann Algan, and Pierre Cahuc, "Civil Society and the State: The Interplay between Cooperation and Minimum Wage Regulation," Journal of the European Economic Association 9:1 (2011), $3-42$.

Alesina, Alberto, Yann Algan, Pierre Cahuc, and Paola Giuliano, "Family Values and the Regulation of Labor," Journal of the European Economic Association 13:4 (2015), 599-630.

Alesina, Alberto, and Nicola Fuchs-Schundeln, "Good-Bye Lenin (Or Not?): The Effect of Communism on People's Preferences," American Economic Review 97:4 (2007), 469-530.

Alesina, Alberto, and Paola Giuliano, "Culture and Institution," Journal of Economic Literature 53:4 (2015), 898-944.

Alesina, Alberto, Paola Giuliano, and Nathan Nunn, "On the Origins of Gender Roles: Women and the Plough," Ouarterly Journal of Economics 128 (2013), 2060-2092.

Algan, Yann, and Pierre Cahuc, "Inherited Trust and Growth," American Economic Review 100:5 (2010), 2060-2092.

Alpern Engel, Barbara, and Anastasia Posadskaya-Vanderbeck, A Revolution of Their Own: Voices of Women in Soviet History (Boulder, CO Westview Press, 1988).

Antecol, Heather, "An Examination of Cross-Country Differences in the Gender Gap in Labor Force Participation Rates," Labour Economics 7:4 (2000), 409-426.

Bau, Natalie, "Can Policy Crowd Out Culture?" University of Toronto mimeograph (2015).

Bauernschuster, Stefan, and Oliver Falck, "Culture, Spatial Diffusion of Ideas and Their Long-Lasting Imprints-Evidence from Froebel's Kindergarten Movement," Journal of Economic Geography 15:3 (2015), 601-630.

Bauernschuster, Stefan, and Helmut Rainer, "Political Regimes and Family: How Sex-Role Attitudes Continue to Differ in Reunified Germany," Journal of Population Economics 25:1 (2011), 5-27.

Beblo, Miriam, and Luise Goerges, "Breaking Down the Wall between Nature and Nurture: An Exploration of Gendered Work Preferences in East and West Germany," WiSo-HH working paper, Universitaet Hamburg 2015.

Becker, Sascha O, Katrin Boeckh, Christa Hainz, and Ludger Woessmann, "The Empire Is Dead, Long Live the Empire! Long-Run Persistence of Trust and Corruption in the Bureaucracy," Economic Journal 126:590 (2016), 40-74.

Bertrand, Marianne, Emir Kamenica, and Jessica Pan, "Gender Identity and Relative Income within Households," Ouarterly Journal of Economics 130:2 (2015), 571-614.

Bisin, Alberto, and Thierry Verdier, "The Economics of Cultural Transmission and the Dynamics of Preferences," Journal of Economic Theorv 97:2 (2001), 298-319.

Black, Sandra E., "Do Better Schools Matter? Parental Valuation of Elementary Education," Quarterly Journal of Economics 114 (1999), 577-599.

Boschini, Anne, Kristin Gunnarsson, and Jesper Roine, "Women in Top Incomes: Evidence from Sweden 1974-2013," IZA discussion paper 10979 (2017).

Buchholz, Hanns, "The Inner-German Border," Carl Grundy-Warr, ed., Eurasia: World Boundaries (London: Routledge, 1994).

Buckley, Mary, "Women in the Soviet Union," Feminist Review 8:1 (1981), 79-106.

Bursztyn, Leonardo, and Davide Cantoni, "A Tear in the Iron Curtain: The Impact of Western Television on Consumption Behavior," this REVIEW 98:1 (2015)

Calonico, Sebastian, Matias D Cattaneo, and Rocio Titiunik, "Optimal Data-Driven Regression Discontinuity Plots," Journal of the American Statistical Association 110:512 (2015), 1753-1769.

Cameron, A. Colin, Jonah B. Gelbach, and Douglas L. Miller, "BootstrapBased Improvements for Inference with Clustered Errors," this REVIEW 90:3(2008), 414-427.

Cooper, Belinda, "The Changing Face of Berlin," World Policy Journal 15:3(1998), 57-68.
David, Henry P., Reproductive Behavior: Central and Eastern European Experience (Berlin: Springer, 2013).

de Haan, Francisca, "Women as the 'Motor of Modern Life"' (pp. 87-103), in Bonnie G. Smith and Joanna Regulska, eds., Women and Gender in Postwar Europe: From Cold War to European Union (New York: Routledge, 2012).

Dell, Melissa, "The Persistent Effects of Peru's Mining Mita," Econometrica 78:6 (2010), 1863-1903.

Della Vigna, Stefano, and Ethan Daniel Kaplan, "The Fox News Effect: Media Bias and Voting," Ouarterly Journal of Economics 122:3 (2007), 1187-1234.

Della Vigna, Stefano Della, Ruben Enikolopov, Vera Mironova, Maria Petrova, and Ekaterina Zhuravskaya, "Cross-Border Media and Nationalism: Evidence from Serbian Radio in Croatia," American Economic Journal: Applied Economics 6:3 (2014), 103-132.

Deutscher Bundestag, "Entwurf eines Gesetzes zur Foerderung des Zonenrandgebietes (Zonenrandfoerderungsgesetz), VI/796 (1970), 7" (1970).

Dhar, Diva, Tarun Jain, and Seema Jayachandran, "Intergenerational Transmission of Gender Attitudes: Evidence from India," NBER working paper 21429 (2015)

Di Tella, Rafael, Sebastian Galiant, and Ernesto Schargrodsky, "The Formation of Beliefs: Evidence from the Allocation of Land Titles to Squatters," Ouarterly Journal of Economics 122:1 (2007), 209-241.

Durante, Ruben, "Risk, Cooperation and the Economic Origins of Social Trust: An Empirical Investigation," SSRN 1576774 (2009).

Eisensee, T., and D. Strömberg, "News Droughts, News Floods, and U.S. Disaster Relief," Ouarterly Journal of Economics 122:2 (2007), 693-728.

Enikolopov, Ruben, Maria Petrova, and Ekaterina Zhuravskaya, "Media and Political Persuasion: Evidence from Russia," American Economic Review 101:7 (2011), 3253-3285.

Farré, Lídia, and Francis Vella, "The Intergenerational Transmission of Gender Role Attitudes and Its Implications for Female Labour Force Participation," Economica 80:318 (2013), 219-247.

Fassmann, Heinz, and Rainer Münz, "European East-West Migration, 1945-1992," International Migration Review 28 (1994), 520-538.

Fernández, Raquel, "Alfred Marshall Lecture: Women, Work, and Culture," Journal of the European Economic Association 5 (2007), 305-332.

Fernández, Raquel, and Alessandra Fogli, "Culture: An Empirical Investigation of Beliefs, Work, and Fertility," American Economic Journal: Macroeconomics 1:1 (2009), 146-177.

Fernández, Raquel, Alessandra Fogli, and Claudia Olivetti, "Mothers and Sons: Preference Formation and Female Labor Force Dynamics," Ouarterly Journal of Economics 119:4 (2004), 1249-1299.

Fodor, Éva, Working Difference: Women's Working Lives in Hungary and Austria, 1945-1995 (Durham, NC: Duke University Press, 2002).

Fogli, Alessandra, and Laura Veldkamp, "Nature or Nurture? Learning and the Geography of Female Labor Force Participation," Econometrica 79:4 (2011), 1103-1138.

Fortin, Nicole M., "The Gender Wage Gap among Young Adults in the United States: The Importance of Money versus People," Journal of Human Resources 43:4 (2008), 884-918.

Fuchs-Schündeln, Nicola, and Rima Izem, "Explaining the Low Labor Productivity in East Germany-A Spatial Analysis," Journal of Comparative Economics 40:1 (2012), 1-21.

Fuchs-Schündeln, Nicola, and Paolo Masella, "Long-Lasting Effects of Socialist Education," this REVIEW 98:3 (2016), 428-441.

Gelman, Andrew, and Guido Imbens, "Why High-Order Polynomials Should Not Be Used in Regression Discontinuity Designs," Journal of Business and Economic Statistics (2018), 1-10.

Gentzkow, Matthew, "Television and Voter Turnout," Quarterly Journal of Economics 121 (2006), 931-972.

GESIS-Leibniz Institute for the Social Sciences, "ALLBUS/GGSS 1980-2012 (Allgemeine Bevölkerungsumfrage der Sozialwissenschaften ALLBUS-Kumulation 1980-2012): Sensitive Geographical Data," GESIS Data Archive, Cologne. ZA5260 Data file Version 2.0.0 (2013), doi:10.4232/1.11639.

GESIS-Leibniz Institut für Sozialwissenschaften, "German General Social Survey (ALLBUS) - Cumulation 1980-2012," GESIS Datenarchiv, Köln. ZA4580 Data file Version 1.0.0 (2014), doi:10.4232/1. 11952.

Giavazzi, Francesco, Ivan Petkov, and Fabio Schiantarelli, "Culture: Persistence and Evolution,” NBER working paper 20174 (2014). 
Giavazzi, Francesco, Fabio Schiantarelli, and Michel Serafinelli, "Attitudes, Policies, and Work." Journal of the European Economic Association 11:6 (2013), 1256-1289.

Giuliano, Paola, "Living Arrangements in Western Europe: Does Cultural Origin Matter?" Journal of the European Economic Association 5:5 (2007), 927-952.

Giuliano, Paola, and Antonio Spilimbergo, "Growing Up in a Recession," Review of Economic Studies 81:2 (2014), 787-817.

Gorodnichenko, Yuriy, and Gerard Roland, "Culture, Institutions and the Wealth of Nations," this REVIEW 99:3 (2017), 402-416.

Grosfeld, Irena, and Ekaterina Zhuravskaya, "Cultural vs. Economic Legacies of Empires: Evidence from the Partition of Poland." Journal of Comparative Economics 43:1 (2015), 55-75.

Guiso, Luigi, Paola Sapienza, and Luigi Zingales, "Does Culture Affect Economic Outcomes?"Journal of Economic Perspectives 20 (2006), 23-48.

Imbens, G. W., and J. D. Angrist, "Identification and Estimation of Local Average Treatment Effects," Econometrica 62:4 (1994), 467-476.

Imbens, Guido, and Tristan Zajonc, "Regression Discontinuity Design with Multiple Forcing Variables," unpublished manuscript (2011).

Jensen, Robert, and Emily Oster, "The Power of TV: Cable Television and Women's Status in India," Ouarterly Journal of Economics 124:3, (2009), 1057-1094.

Kim, Byung-Yeon, Syngjoo Choi, Jungmin Lee, Sokbae Lee, and Kyunghui Choi, "Do Institutions Affect Social Preferences? Evidence from Divided Korea," University College London mimeograph (2015).

Klüsener, Sebastian, and Joshua R. Goldstein, "A Long-Standing Demographic East-West Divide in Germany," Population, Space and Place 22:1 (2016), 5-22.

La Ferrara, Eliana, Alberto Chong, and Suzanne Duryea, "Soap Operas and Fertility: Evidence from Brazil," American Economic Journal: Applied Economics 4:4 (2012), 1-31.

Lalive, Rafael, "How Do Extended Benefits Affect Unemployment Duration? A Regression Discontinuity Approach," Journal of Econometrics 142:2 (2008), 785-806.

Lippmann, Quentin, Alexandre Georgieff, and Claudia Senik, "Undoing Gender with Institutions. Lessons from the German Division and Reunification," PSE working paper (2016).
Lowes, Sara, Nathan Nunn, James A. Robinson, and Jonathan Weigel, "The Evolution of Culture and Institutions: Evidence from the Kuba Kingdom," Econometrica 85:4 (2017), 1065-1091.

Mazower, Mark, Dark Continent: Europe's Twentieth Century (New York: Vintage Books, 2009).

McMahon, Robert J., The Cold War: A Very Short Introduction (New York: Oxford University Press, 2003).

Michau, Jean-Baptiste, "Unemployment Insurance and Cultural Transmission: Theory and Application to European Unemployment," Journal of the European Economic Association 11:6 (2013), 1320-1347.

Misiunas, Romuald J., and Rein Taagepera, The Baltic States, Years of Dependence, 1940-1990 (Berkeley: University of California Press, 1993).

Molyneux, Maxine, Women's Movements in International Perspective: Latin America and Beyond (London: Palgrave Macmillan, 2001).

Moretti, Enrico, "Real Wage Inequality," American Economic Journal: Applied Economics 5:1 (2013), 65-103.

Olkean, Benjamin A., "Do Television and Radio Destroy Social Capital? Evidence from Indonesian Villages," American Economic Journal: Applied Economics 1:4 (2009), 1-33.

Peisakhin, Leonid V., "Living Historical Legacies: The 'Why' and 'How' of Institutional Persistence-The Case of Ukraine." SSRN 1666548 (2010).

Schumann, Abel, "Persistence of Population Shocks: Evidence from the Occupation of West Germany after World War II," American Economic Journal: Applied Economics 6:3 (2014), 189-205.

Shaffer, Harry, Women in the Two Germanies: A Comparison of a Socialist and a Non-Socialist Society (New York: Pergamon Press, 1981).

Tabellini, Guido, "The Scope of Cooperation: Values and Incentives," Ouarterly Journal of Economics 123:3 (2008), 905-950.

Trappe, Heike, "Work and Family in Women's Lives in the German Democratic Republic," Work and Occupations 23:4 (1996), 354-377.

Voigtländer, Nico, and Hans-Joachim Voth, "Persecution Perpetuated: The Medieval Origins of Anti-Semitic Violence in Nazi Germany," Ouarterly Journal of Economics 127:3 (2012), 1339-1392.

Wolchik, Sharon L., "Ideology and Equality The Status of Women in Eastern and Western Europe," Comparative Political Studies 13:4 (1981), 445-476. 


\section{This article has been cited by:}

1. Thiess Buettner, Katharina Erbe, Veronika Grimm. 2019. Tax planning of married couples and intra-household income inequality. Journal of Public Economics 179, 104048. [Crossref]

2. Roman Bobilev, Anne Boschini, Jesper Roine. 2019. Women in the Top of the Income Distribution: What Can We Learn From LIS-Data?. Italian Economic Journal 16. . [Crossref]

3. Sergio Galletta, Elliott Ash, Daniel L. Chen. 2019. Do Judicial Sentiments Affect Social Attitudes?. SSRN Electronic Journal . [Crossref]

4. Sergio Galletta. 2018. Decision-Making Institutions and Voters' Preferences for Fiscal Policies. SSRN Electronic Journal . [Crossref]

5. Duman Bahrami-Rad. 2018. Keeping It in the Family: Female Inheritance, Inmarriage, and the Status of Women. SSRN Electronic Journal . [Crossref]

6. Thiess Buettner, Katharina Erbe, Veronika Grimm. 2017. Tax Planning of Married Couples and Intra-Household Income Inequality. SSRN Electronic Journal . [Crossref]

7. Edoardo Teso. 2016. The Long-Term Effect of Demographic Shocks on the Evolution of Gender Roles: Evidence from the Transatlantic Slave Trade. SSRN Electronic Journal . [Crossref]

8. Louise A. Grogan, Fraser Summerfield. 2015. Government Transfers, Work and Social Norms: Evidence from the Russian OldAge Pension, 1990-2011. SSRN Electronic Journal . [Crossref]

9. Melanie Meng Xue. 2014. Textiles and the Historical Emergence of Gender Equality in China. SSRN Electronic Journal . [Crossref] 